ZOOLOGIA 31 (4): 400-404, August, 2014

http://dx.doi.org/10.1590/S1984-46702014000400012

\title{
A new species and records of Helochares (Insecta: Coleoptera: Hydrophilidae) from Southeastern Brazil
}

\author{
Bruno Clarkson ${ }^{1,2} \&$ Nelson Ferreira-Jr ${ }^{1}$
}

\begin{abstract}
${ }^{1}$ Laboratório de Entomologia, Departamento de Zoologia, Instituto de Biologia, Universidade Federal do Rio de Janeiro. Caixa Postal 68044, 21941-971 Rio de Janeiro, RJ, Brazil.E-mail: brclarkson@gmail.com; nferrejr@gmail.com

2 Programa de Pós-graduação em Ciências Biológicas - Zoologia, Museu Nacional, Universidade Federal do Rio de Janeiro. Quinta da Boa Vista, São Cristóvão, 20940-040 Rio de Janeiro, RJ, Brazil.
\end{abstract}

\begin{abstract}
A new species of Helochares Mulsant, 1844 (Hydrophilidae: Acidocerinae) from Brazil is described and illustrated. Helochares (s. str.) atlanticus sp. nov. is distinct mainly by characteristics of the aedeagus whose phalobase is short, narrowed on basal third; parameres are thick, constricted on apical quarter, with small tooth-like projection on outer margin near apex; dorsal lobe longer than ventral lobe, shorter than parameres, very wide at base, abruptly narrowing toward apex until about half of its length where it dilates and divides into two long and narrow projections apart from each other at base, but turned inward at apex; ventral lobe acuminate and symmetrical. The rounded emargination on anteromedial margin of labrum bearing small tooth-like projections and the convex and slightly elevated mesoventral process, without high-elevated carina, also helps in identifying the species. Specimens of the new species were collected in the mountain region of the state of Rio de Janeiro (municipality of Teresópolis) and in the north coast of the state of São Paulo (municipality of Ubatuba), both localities in Southeastern Brazil. Helochares (s. str.) oculatus Sharp, 1882 and Helochares (Sindolus) femoratus (Brullé, 1841) are recorded for the first time from the state of Rio de Janeiro.
\end{abstract}

KEY WORDS. Acidocerinae; description; Neotropics; new records; taxonomy.

The cosmopolitan Helochares Mulsant, 1844 currently comprises about 180 valid species divided into five subgenera: H. (Batochares) Hansen, 1991 (three species); H. (Helocharimorphus) Kwert, 1890 (three species); H. (Hydrobaticus) MacLeay, 1871 (128 species); H. (s. str.) Mulsant, 1844 (38 species); and H. (Sindolus) Sharp, 1882 (eight species) (HANsen 1999, SHORT \& Hebauer 2006, SHORT \& FiKÁceK 2011). Of these, three species of H. (Hydrobaticus), 15 of $H$. (s. str.) and all described species of $H$. (Sindolus) are known from the Neotropical Region. In South America, there are 11 species of $H$. (s. str.) and six species of $H$. (Sindolus) (Hansen 1999, Short \& Hebauer 2006, Short \& Fikácek 2011).

Ten species of Helochares are known from Brazil (HANSEN 1999): H. (s. str.) abbreviatus (Fabricius, 1801), from the state of Espírito Santo (Orсhymont 1926); H. (s. str.) atatus Bruch, 1915, from the states of Mato Grosso do Sul and Minas Gerais (Orchymont 1939); H. (s. str.) chaquensis Fernández, 1982 from Mato Grosso do Sul (Fernández 1982b); H. (s. str.) inornatus Orchymont, 1926 from the states of São Paulo (Orchymont 1926) and Amazonas (Balfour-Browne 1939); H. (s. str.) oculatus Sharp, 1882 from Mato Grosso do Sul (Orchymont 1939) and the state of Pernambuco (Orchymont 1943); H. (s. str.) pallipes (Brullé, 1841) from Minas Gerais (Orchymont 1926) and Mato Grosso do Sul (Fernández 1983); H. (s. str.) tectiformis Fernández,
1982, from Mato Grosso do Sul (Fernández 1982b); H. (Sindolus) femoratus (Brullé, 1841), from the state of Rio Grande do Sul (Orchymont 1939); H. (Sindolus) mesostitialis Fernández, 1981 from Mato Grosso do Sul (Fernández 1981); and H. (Sindolus) ventricosus Bruch, 1915 from Amazonas and Mato Grosso do Sul (FERNÁNDEZ 1982a). Unidentified species of the genus was reported from an undisclosed locality in the state of Rio de Janeiro by SANTOS et al. (2009), and for the municipality of Maricá in the same state by FerReIra-Jr et al. (1998).

In this paper, species of Helochares from the state of Rio de Janeiro are named for the first time, with the description of $H$. (s. str.) atlanticus sp. nov. and new records for $H$. (s. str.) oculatus and $H$. (S.) femoratus.

\section{MATERIAL AND METHODS}

All specimens were examined using a binocular Leica S8AP0 microscope (80x). Measurements were taken using a binocular Coleman microscope (100x) with the aid of an ocular micrometer. The description and measurements of the new species were based on the holotype. Male genitalia were dissected, stored in a microvial and maintained with the specimen in a vial containing alcohol 90\%. Photographs were taken from paratype specimens with a Microptics system. Between 15 and 
25 images were taken for each figure. Images were aligned and stacked using the Combine $\mathrm{Z}$ software in the Division of Entomology, Natural History Museum, University of Kansas, USA and in the Laboratório de Entomologia, Instituto de Biologia, Universidade Federal do Rio de Janeiro, Brazil. Drawings were prepared from photographs using the Adobe Illustrator software. Geotagging was done after the specimens were collected. The coordinates (datum: WGS-84) are thus approximate and may not correspond to the exact spot where the specimens were found. The morphological terminology follows mainly KOMAREK (2004) with some terminology adapted from FERNÁNDEZ (1982a, b, 1989) and SHort (2005). Measurements presented for the holotype follow largely those proposed by OLIVA (1989) for species of Berosus Leach, 1817. All examined specimens are deposited in the Coleção Entomológica Prof. José Alfredo Pinheiro Dutra, Instituto de Biologia, Universidade Federal do Rio de Janeiro, Rio de Janeiro - DZRJ (curator: Nelson Ferreira-Jr).

\section{TAXONOMY}

\section{Helochares Mulsant, 1844}

Enhydrus Dahl, 1823: 34 (partim) (nom. nud., rejected name, ICZN 1964: 242).

Enhydrus MacLeay, 1825: 35 (suppressed, ICZN 1964: 242).

Helophilus Mulsant, 1844: 132 (nec Leach, 1817) (rejected name, ICZN 1964: 242).

Helochares Mulsant, 1844: 197 (replacement name for Helophilus Mulsant, 1944).

Helocharis Thomson, 1859: 18 (incorrect subsequent spelling).

Type species. Dytiscus lividus Forster, 1771 (subsequent designation by Thomson, 1859: 18, fixed by ICZN 1964: 242).

Remarks. The subgenera of Helochares from the Neotropics are usually easily distinguished by the mesoventral aspect - elevated forming high longitudinal laminar keel in $H$. (Sindolus) spp. or at most convex, with or without median carina that is never strongly raised in $H$. (s. str.) and $H$. (Hydrobaticus) spp. and/or by the general morphology of the aedeagus - narrow with rather straight and parallel outer margins, median lobe distinctly longer than parameres in $H$. (Hydrobaticus) spp., while $H$. (s. str.) and H. (Sindolus) present a wide aedeagus, usually with sinuate outer margins, median lobe shorter than parameres. However, species of these subgenera show intraspecific variation - e.g., on dorsal sculpture patterns - and homogeneity in many characters - e.g., on ventral aspect of the thoracic plates, legs and abdomen - and differences between species are found mainly in the male genitalia. Therefore, it is strongly recommended that identifications are confirmed after examination of the morphology of the aedeagus (SHORT 2005). Following the descriptions of FerNÁndez (1982a, b, 1989) we describe in this paper the median lobe divided into sclerotized dorsal lobe and membranous ventral lobe, which may be more or less developed in the South American species.

\section{Helochares (s. str.) atlanticus sp. nov.} Figs 1-7

Diagnosis. Large-sized species (9.00-9.90 mm). Dorsum dark brown, with pronotal and elytral margins brown (Fig. 1). Labrum with wide rounded emargination on anteromedial margin, toothed (Fig. 3). Clypeus with distinct systematic punctures forming a short, irregular row on anterolateral margins (Fig. 4). Dorsal sculpture on elytra slightly marked, with sparse systematic punctures (Fig. 1). Prosternum without carina (Fig. 5). Mesoventrite with convex elevation, slightly carinate anteriorly (Fig. 6). Aedeagus (Fig. 7) with dorsal lobe longer than ventral lobe and shorter than parameres, very wide at base, abruptly narrowing toward apex until about half of its length where it dilates and divides into two long narrow projections; projections are apart from each other at base but are turned inward and touch at apex; apex rounded. Ventral lobe acuminate, symmetrical.

Description. Holotype male. Total length $9.40 \mathrm{~mm}$; maximum width $4.70 \mathrm{~mm}$; maximum width of head $2.10 \mathrm{~mm}$; elytral length $6.10 \mathrm{~mm}$; maximum width of pronotum $4.20 \mathrm{~mm}$; humeral width $4.20 \mathrm{~mm}$; maximum height $2.70 \mathrm{~mm}$. Body oval, slightly convex (Figs 1 and 2).

Color. Dorsum of head dark brown, labrum brown with anterior half paler. Pronotum dark brown, margins brown. Elytra uniformly dark brown, external margins brown (Fig. 1). Labial palpi and antennae brown. Maxillary palpi dark brown, with distal portion of each palpomere paler (Figs 1 and 2). Ventral face and legs uniformly dark brown (Fig. 2).

Head. Ground punctation on labrum, frons and clypeus fine and dense, evenly distributed, punctures about same width of one ommatidium, distance between punctures 0.5-2.0 $\times$ the width of one puncture. Systematic punctures on labrum consisting of scattered punctures on medial portion and anterolateral margins, about twice larger than surrounding punctures, bearing short, fine setae; anterolateral punctures with somewhat longer setae. Labrum with wide rounded emargination on anteromedial margin, bearing small conical projections giving toothed surface appearance (Fig. 3). Clypeus with short, irregular row of distinct systematic punctures on both anterolateral portions, and some scattered ones on clypeal disc, about twice larger than surrounding punctures, bearing short, fine setae. Frontoclypeal suture well marked (Fig. 4). Frons with irregular row of distinct systematic punctures along frontoclypeal suture at both sides, restricted to lateral third of frons, and scattered ones mesally of eyes, both about 2.0-3.0 $\times$ larger than surrounding punctures and bearing short, fine setae (Fig. 4). Maxillary palpi longer than maximum width of head $(0.3 \times$ longer); apical palpomere slightly longer than penultimate $(0.2$ $\times$ longer), palpomeres 2 and penultimate subequal in length (Figs 1 and 2). Labial palpi about half of width of mentum. Mentum rugose, with sparse setae and rows of short setae along lateral margins; anterolateral margins elevated, anterocentral half depressed; lateral margins subparallel. 

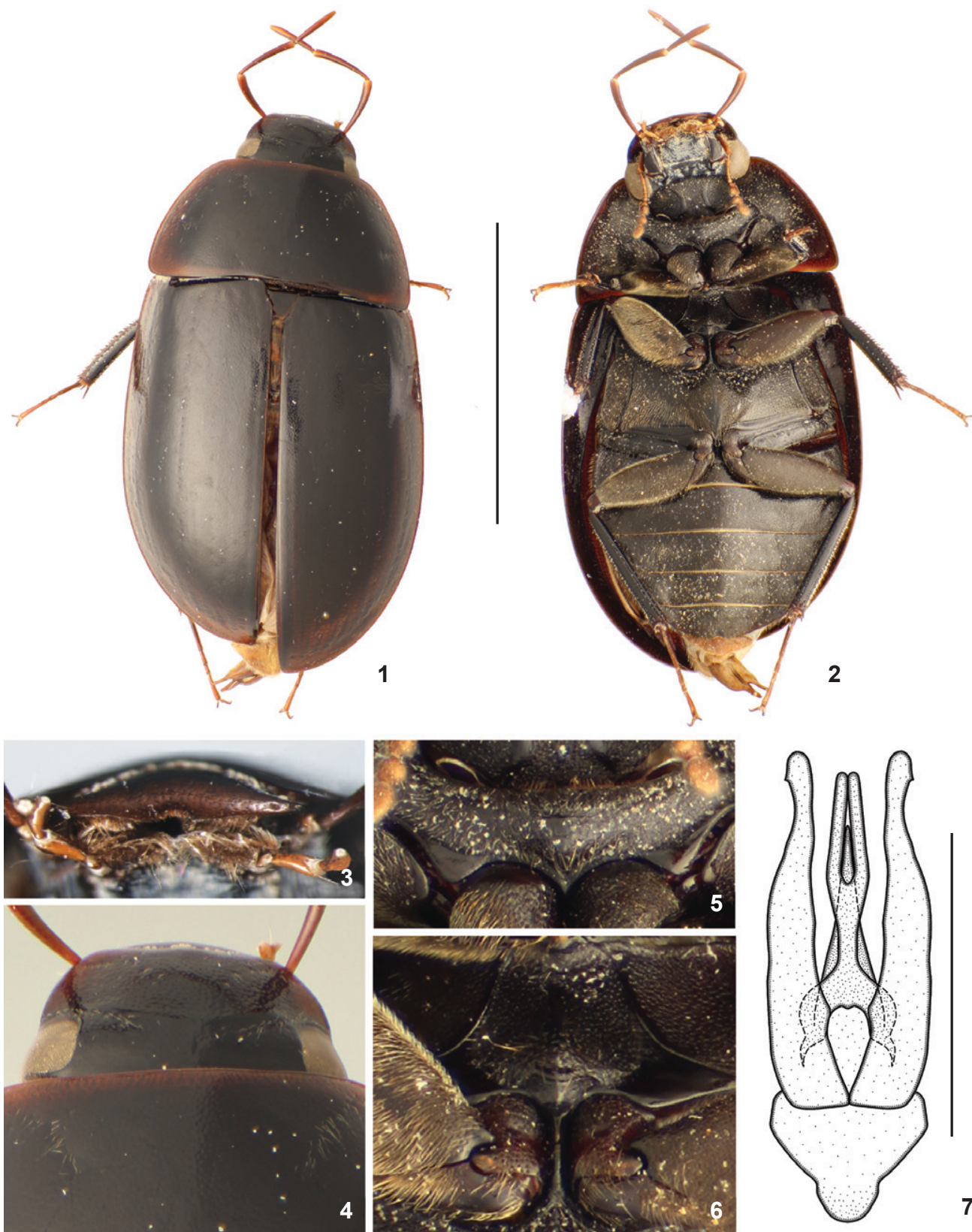

Figures 1-7. Helochares (s. str.) atlanticus sp. nov.: (1) habitus in dorsal view; (2) habitus in ventral view; (3) labrum; (4) head and part of pronotum in dorsal view; (5) prosternum; (6) mesoventrite; (7) aedeagus in dorsal view. Scale bars: 1-2 = 4.5 mm, $7=1 \mathrm{~mm}$.

Thorax. Ground punctation on pronotum and elytra evenly distributed, fine and dense, interstices with fine microsculpture, giving a slightly rugose aspect to surface. Pronotum with a wide area of irregularly spaced systematic punctures on anterior two-thirds of lateral portions, about twice wider than surrounding punctures; two anterolateral and two posterolateral series of contiguous systematic punctures bear- ing short, fine setae, anterior series curved backward, beginning near lateral margin toward medial portion of pronotum, posterolateral ones perpendicular to lateral margin, short and weakly marked (Fig. 1). Marginal bead present along whole pronotal margins; posterior margin arcuate (Fig. 1). Elytra with ten weakly defined longitudinal striae. Systematic punctures arranged in rows, irregularly spaced, about twice larger than 
ground punctures, bearing rather long, fine setae (Fig. 1); scutellar striae present (Fig. 1); anterolateral margins of elytra with narrow depression in which pronotal posterior margins fit. Prosternum finely pubescent, slightly convex, without medial carina (Fig. 5). Mesoventrite convex, elevated medially on posterior half, bearing long setae, slightly carinate anteriorly (Fig. 6). Metaventrite densely punctate, sparsely pubescent; with posteromedial, elongate oval, glabrous area, longer than wide, about half of total length of metaventrite (Fig. 2). Middle and hind femora densely pubescent, glabrous only on distal eighth (Fig. 2).

Abdomen. Ventrites densely pubescent; lateral and posterior margins glabrous. Ventrite 5 with shallow apical emargination, distinctly wider than deep, lined with coarse yellow setae (Fig. 2). Aedeagus (Fig. 7) $1.6 \mathrm{~mm}$ long. Phallobase symmetrical, short, about a quarter of aedeagus length, wider than distal portion of aedeagus, maximum width on apical third; manubrium distinct, narrow, rounded at base, about one-third the length of phallobase. Parameres thick, inner margins slightly sinuate, outer margins conspicuously sinuate, constricted on distal quarter, apex slightly convex laterally, rounded on top, with small tooth-like projection on outer margin near apex. Dorsal lobe longer than ventral lobe, shorter than parameres, very wide at base, abruptly narrowing toward apex until about half of its length where it dilates and divides into two long, narrow projections; these projections are apart from each other at base but are turned inward and touch at apex; apex rounded. Ventral lobe acuminate at apex, symmetrical.

Intraspecific variation. Body length from $9.10 \mathrm{~mm}$ to 9.90 $\mathrm{mm}$ in males $(\mathrm{n}=5)$, from $9.00 \mathrm{~mm}$ to $9.50 \mathrm{~mm}(\mathrm{n}=2)$ in females. Elytral striae can be slightly impressed and visible or less impressed and practically invisible. However, the striae are distinguishable by the presence of sparse systematic punctures arranged in rows along the elytra.

Material examined. Holotype male. "BRASIL: São Paulo, Ubatuba, Parque/Estadual da Serra do Mar,/Núcleo Picinguaba, Poça na borda/da Mata/11.VI.2001/Ferreira Jr, N. col." (DZRJ: Coleoptera 1765). Paratypes (6). BRAZIL: São Paulo: Ubatuba: Parque Estadual da Serra do Mar: Núcleo Picinguaba: 1 specimen, "Poça no caminho da Casa da Farinha, 04.VI.2000, Carvalho, A. L. col." (DZRJ: Coleoptera 1482); 3 specimens, same data, "03/ VI/2000, Ferreira Jr, N. \& Nicollini, L. B. col.” (DZRJ: Coleoptera 1484, 1764); BRASIL: Rio de Janeiro: Teresópolis: Faz. Vale da Revolta: 2 specimens, "Poça na Mata, 12.X.1996, 22²6'56"S $42^{\circ} 56^{\prime} 31^{\prime \prime}$, Ferreira Jr, N. col." (DZRJ: Coleoptera 1485).

Etymology. The specific name atlanticus (Latinized) refers to the distribution of the type-series, corresponding to the Atlantic Rain Forest area.

Taxonomic notes. The new species is rather similar to Helochares (s. str.) bolivianus Fernández, 1989 mainly in body length, dorsal sculpture and aedeagus characteristics. It can be distinguished from that species by the shape of the dorsal lobe, which shows projections placed apart from each other basally and directed inward apically (Fig. 7). The overall aspect of the aedeagus of $H$. (s. str.) atlanticus sp. nov. (Fig. 7) resembles that of $H$. (s. str.) coya Fernández, 1982 and $H$. (s. str.) tectiformes Fernández, 1982. but it can be easily separated from the former by having wider parameres, narrowed only on distal fourth, by the dorsal lobe strongly constricted on basal half, with projections directed inward, without tooth-like projections on outer margin; and from the latter by the parameres less convergent, dorsal lobe more strongly constricted on basal half, bifurcated near base of aedeagus. Externally, H. (s. str.) atlanticus sp. nov. differs from both species by the mesoventrite with a convex and weak elevation, which is not tectiform (Fig. 6).

Biology. The holotype and one paratype were collected in the mountainous region of Rio de Janeiro, in an area of Atlantic Rain Forest, municipality of Teresópolis, at ca. $1150 \mathrm{~m}$ a.s.l. The other components of the type-series were collected in the state of São Paulo, near the border with Rio de Janeiro, at sea level. The specimens were collected from temporary ponds that have leaf litter and aquatic vegetation. These ponds were covered and shaded in the border of the forest, or were in open areas.

\section{New records}

Helochares (s. str.) oculatus Sharp, 1882. Geographic distribution: Argentina, Brazil (states of Mato Grosso do Sul and Pernambuco), Guatemala and Panamá.

New record for the state of Rio de Janeiro: Macaé, Maricá and Teresópolis municipalities.

Material examined. BRAzIL, Rio de Janeiro: Maricá, 4 specimens, "Restinga de Maricá, Poça, 08.VII.1996, Ferreira JR, N. col." (DZRJ: Coleoptera 1471); 7 specimens, same data, different dates "12.XI.1988", "30.I.1996", "21.VIII.1996" (DZRJ: Coleoptera 1473, 1475, 1476, 1477, 1486, 1488); 3 specimens, same data, “26.IX.1986, Ferreira-Jr, N. \& Carvalho, A. L. col." (DZRJ: Coleoptera 1481); Macaé, 1 specimen, "Rio Macaé, 16.VIII.2001, Ferreira Jr, N. col." (DZRJ: Coleoptera 1745); Teresópolis, 1 specimen, "Faz. Vale da Revolta, poça dentro da mata, abaixo da casa, 19.VIII.1996, 22 26 $26^{\prime} 56^{\prime \prime} \mathrm{S} 42^{\circ} 56^{\prime} 31^{\prime \prime} \mathrm{O}$, Ferreira Jr, N. \& Carvalho, A. L. col." (DZRJ: Coleoptera 1752).

Helochares (Sindolus) femoratus (Brullé, 1841). Geographic distribution: Argentina and Brazil (state of Rio Grande do Sul).

New record for the state of Rio de Janeiro: Macaé municipality.

Material examined. 1 specimen, "BRASIL: Rio de Janeiro, Macaé, Lagoa Cabiúnas, 10.VIII.2000, 22²17'24.23"S 4141' 40.68"O, Ferreira Jr, N. \& Nicollini, L. B. col." (DZRJ: Coleoptera 1480).

\section{ACKNOWLEDGMENTS}

We are thankful to the staff of the Laboratório de Entomologia (Instituto de Biologia, UFRJ) for encouragement and aid; Guilherme Muricy, Daniela M. Takiya, Leonardo G. Azevedo, Marcela L. Monné, Maria Inês dos Passos, and Gabriel Mejdalani for their advice and for reviewing an earlier version 
of this manuscript; Andrew Short for providing assistance with the identification of the new species for reviewing the manuscript; Inês C. Gonçalves and Daniel A. Ferreira for reviewing the English; to N.S. Amparo and S. Jorge for support. Financial support was provided by Conselho Nacional de Desenvolvimento Científico e Tecnológico (CNPq, 143268/2011-2) and Fundação de Amparo à Pesquisa do Estado do Rio de Janeiro (FAPERJ).

\section{LITERATURE CITED}

Balfour-Browne, F. 1939. Contribution on the study of the Palpicornia - Part III. Annals and Magazine of Natural History 11 (4): 289-310.

DAнL, G. 1823. Coleoptera und Lepidoptera. Ein systematisches Verzeichniss, mit beygesetzten Preisen der Vorräthe. Wien, J.E. Akkermann, 105p.

Fernández, L.A. 1981. Dos especies nuevas del género Helochares (Coleoptera: Hydrophilidae). Revista de la Sociedad Entomológica Argentina 39 (3-4): 271-277.

Fernández, L. A. 1982a. Notas sobre el género Helochares (Insecta, Coleoptera: Hydrophilidae). Neotropica 8 (79): 31-40.

Fernández, L.A. 1982b. Cinco especies nuevas del género Helochares (Coleoptera: Hydrophilidae). Physis (Buenos Aires), secc. b, 40 (99): 85-90.

Fernández, L.A. 1983. Helochares (Sindolus) talarum sp. nov., y redescripción de Helochares (Helochares) pallipes (Brullé), con descripción de los estados preimaginales (Coleoptera: Hydrophilidae). Limnobios 2(6): 439-449.

FernándeZ, L.A. 1989. Notas sobre el género Helochares. II (Coleoptera: Hydrophilidae). Descripción de dos especies nuevas neotropicales. Clave para determinar las especies argentinas y de áreas vecinas. Revista de la Sociedad Entomológica Argentina 45 (1-4): 145-151.

Ferreira Jr, N.; E.C. Mendonça; L.F.M. Dorvillé \& J.R.I. Ribeiro. 1998. Levantamento preliminar e distribuição de besouros aquáticos (Coleoptera) na Restinga de Maricá, Maricá - RJ, p. 129-140. In: J.L. Nessimian \& A.L. Carvalho (Eds). Ecologia de insetos aquáticos. Oecologia Brasiliensis. Rio de Janeiro, PPGE-UFRJ, vol. 5.

Hansen, M. 1999. Hydrophiloidea (s. str.) (Coleoptera). World Catalogue of Insects 2. Stenstrup, Apollo Books, 416p.
ICZN. 1964. Opinion 710. Enhydrus Laporte, 1834 (Insecta, Coleoptera): Validated under the plenary powers. Bulletin of Zoological Nomenclature 21: 242-245.

KomareK, A. 2004. Taxonomic revision of Anacaena Thomson, 1859. I. Afrotropical species (Coleoptera: Hydrophilidae). Koleopterologische Rundschau 74: 303-349.

MACLEAY, W. 1825. Annulosa Javanica or an attempt to illustrate the natural affinities and analogies of the insects collected in Java by Thomas Horsfield, M.D. F.L. \& G.S. and deposited by him in the Museum of the Honourable East-India Company. London, Kingsbury, Parbury, and Allen, 50p.

Mulsant, E. 1844. Histoire Naturelle des Coléoptères de France. Palpicornies. L. (errata et addenda: 197) L. Maison, Paris, Ch. Savy Jeune, Lyon, 7+1961p.

Oliva, A. 1989. El género Berosus (Coleoptera: Hydrophilidae) en América del Sur. Revista del Museo Argentino de Ciencias Naturales "Bernardino Rivadavia", Entomología 6 (4): 57-236.

Orchymont, A. D'. 1926. Contribution à l'étude des Hydrophilides VI. Bulletin et Annales de la Société Entomologique de Belgique 66: 201-248.

Orchymont, A. D'. 1939. Notes sur quelques Palpicornia de la Republique Argentine. Revista de la Sociedad Entomológica Argentina 10 (2): 253-264.

Orchymont, A. D'. 1943. Faune du nord-est Brésilien. Mémoires du Musée Royal d'Histoire Naturelle de Belgique 10 (28): 1-85.

Santos, A. D.; B. Clarkson \& N. Ferreira-Jr. 2009 [2010]. Hydrophilidae (Insecta, Coleoptera) do Estado do Rio de Janeiro - Brasil: lista de espécies e novos registros. Arquivos do Museu Nacional 67 (3-4): 329-336.

SHORT, A.E.Z. 2005. A review of the subtribe Acidocerina with special reference to Costa Rica (Coleoptera: Hydrophilidae). Koleopterologische Rundschau 75: 191-226.

Short, A.E.Z. \& F. Hebauer. 2006. World catalogue of Hydrophiloidea (Coleoptera) - additions and corrections, I (1999-2005). Koleopterologische Rundschau 76: 315-359.

SHort, A.E.Z. \& M. FiKÁcEK. 2011. World catalogue of the Hydrophiloidea (Coleoptera): additions and corrections II (2006-2010). Acta Entomologica Musei Nationalis Pragae 51 (1): 83-122.

Thomson, C.G. 1859. Skandinaviens Coleoptera. Lund, Berlingska Boktryckeriet, vol. 1, 290p.

Submitted: 17.II.2014; Accepted: 06.VII.2014.

Editorial responsibility: Gabriel L.F. Mejdalani

ZOOLOGIA 31 (4): 400-404, August, 2014 